\title{
PARENTING STYLES, PARENTING PRACTICES AND ADHD: PREDICTING OPPOSITIONAL DEFIANT BEHAVIOUR IN SCHOOL AND HOME SETTING
}

\author{
AYSHA SHERAZ*1 AND NAJMA NAJAM ${ }^{2}$ \\ ${ }^{1}$ Institute of Applied Psychology, University of the Punjab, Lahore, Pakistan \\ ${ }^{2}$ Institute of Applied Psychology, University of the Punjab, Lahore, Pakistan \\ Email: ayshasheraz9@gmail.com
}

\begin{abstract}
The present research aimed at investigating the relationship amongparenting styles, parenting practices, attention deficit hyper activity disorder (ADHD) and oppositional defiant behaviour (ODB) among school going boys. The study hypothesizes a) a positive relationship among authoritarian, permissive parenting styles, relevant practices and ODB while negative relationship between authoritative parenting styles and ODB in school as well as home settings, $\boldsymbol{b}$ ) positive relationship between ADHD and ODB in school as well as home settings and c) $O D B$ will be predicted from parenting styles, parenting practices and ADHD. The reporting participants about boys $(N=200)$ included teachers $(N=40)$ and parents $(N=400)$. The ODB \& ADHD was measured by Child and Adolescent Disruptive Behaviour inventory (Burns, 2010) and parenting styles by Parenting Styles and Dimensions Questionnaire (Robinson, Mandelco, Olsen, \& Hart, 2001). Authoritarian/ permissive styles were significantly correlated with $O D B$ and fathers' permissiveness, authoritative style and ADHD came out to be significant predictors, differentially across two settings.
\end{abstract}

Keywords: Oppositional defiant behaviour; parenting styles; parenting practices; ADHD

1. Introduction: Research on externalizing behaviour and disruptive behaviour has shown the Oppositional defiant behaviour among many others was prominent reasons for which children or youngsters had been recommended to youth psychological /emotional health services beside conduct disorder and ADHD [1]. Oppositional behavior is a disobedient uncooperative behavior. An increase in number of symptoms and intensity of oppositional behavior leads to the diagnosis of Oppositional Defiant Disorder (ODD). The present research uses the following definition to define the construct of oppositional behaviour which is as follows "oppositional defiant disorder (ODD) as a recurrent pattern of negativistic, defiant, disobedient and hostile behaviour toward authority figures. Mostly, the target of the ODD is authority figures but can be directed toward peers as well. It is the distinctive behavior of either a young child or growing adolescent that is labeled as challenging" [2].

The refinement of Oppositional Defiant Behavior construct has shown that children displaying ODD are inclined to exhibit context specific behavior, which usually occurs in home setting; however there are chances for behavior generalization in other settings. During the development, oppositional behavior may become either target or situation specific at different stages $[3,4]$. Research had recurrently shown that the way parent-child interacts with each other is significantly associated with childhood noncompliant \& defiant behavior patterns. Parenting style is stable parental attitudes, emotional climate created in home for parent child interaction [5] use in educating their children

The oppositional defiant disorder not only a high occurring disorder, reasonably having high comorbidity with other disruptive or psychiatric disorders including ADHD the most common. According to DSM -V [6] ADHD is characterized by a pattern of behaviour, present in multiple settings (e.g., school and home), that can result in performance issues in social, educational, or work 
settings. The symptoms are inattention, hyperactivity and impulsivity that include behaviors like failure to pay close attention to details, etc.

2. Literature review.There has been an established connection between specific discipline practices and conduct difficulties in children as well as grownups [7,8]. According to Social learning theory, strict and unpleasantly stern behaviour of care provider leads to the development of aggressive behaviour in children through the process of learning.Loeber and Stouthamer-Loeber [9] conducted a meta-analysis of over three hundred studies and found that $85 \%$ of concurrent analyses showed a significant relation between dysfunctional parenting practices and conduct problems in children and adolescents.

The research on different dimensions of parenting has shown that authoritarian parenting, having high behavioral control in terms of harsh and punitive control [10] lesser warmth, and indulgent open minded parenting, characterized by lack of behavioral regulation, are related to different types of instability, for example, inhibited behavior, and conduct syndromes [11,12,13].Poor parenting styles i.e., uninvolved, snubbing and strict methods have been linked to problem behavior in children [14].More specifically, troublesome, unruly or disruptive problems have been associated with parental method that is punitive, over reactive, coercive $[15,16]$, indulgent, and unreliable $[17,18]$.

A high level of behavioural control(e.g., boundary setting) i.e., considered to be firm and consistent discipline [19] had been reported to reduce the level of behavioural problems, e.g., hostile/criminal behaviour and conduct disorders, among teenagers [20,21] as well as children at primary school level [19,22]. These results have been attributed to the fact that behavioral control fosters self-regulation and compliance [10,22].

The authors of the present researchSheraz and Najam[23]also conducted a pilot study to explore if the pattern of relationship among different parenting styles and oppositional behavior were similar in Pakistani boys as reported in foreign literature,the findings were in line with previous research indicating a significant positive relationship of authoritarian and permissive parenting styles of both parents with boys' oppositional defiant behaviour toward adults and toward sibling as reported by mother.

Apart from parenting factors, the difficult temperament at birth or biological inclination to hyperactivity estimated to have a high rate of co-occurrence with Oppositional defiant disorder. In a study it was predicted that as much as $80 \%$ children who were diagnosed with ODD had also qualified the standard criteria for ADHD [24]. Kim, Park, Cheon, Kim, Cho, and Hong Kang-E,[25]reported that twenty six percent of children were found to be having co variation between oppositional defiant and attention deficit hyper activity disorder in a Koreans sample.

3. Significance/ Rationale. Research above mentioned, had explicitly stated about the critical and significant role i.e. of parenting techniques in the development of behavior problem. Oppositional behaviour having association with parenting factor is often found to have a co-occurring behaviour pattern marked by attention deficit hyperactivity-in attention type or hyperactivity. Although, enormous literature available on oppositional defiant behavior from clinical/ therapeutic perspective.

Conversely, inquiry in to the relevant literature on the specific parenting factors of oppositional behaviour was mostly referred to overlapping categories such as conduct disorder and broad-band dimensions e.g., externalizing behavior, antisocial behavior. This indicates a gap in the research (as indicated by absence of literature). Thus, the present study is hoped to add and document to fill in gaps in the existing literature.

Hypotheses:

On the bases of above mentioned literature following hypotheses are formulated.

There will be a) significant positive relationship among authoritarian, permissive parenting styles, relevant practices and ODB in school and home while negative

Relationship between authoritative parenting and ODB in school as well as home settings b) a positive relationship between ADHD and ODB in school as well as home settings and c) parenting styles, parenting practices and will predict

\section{Methodology}

4.1. Sample: The participants were mothers, fathers, and teachers of 200 school boys (3 to 10 grade) from five public schools in the city of Lahore. The demographic characteristics of the participants are presented in table 1. 
Teachers, family and boys characteristics (demographic variables) as a frequency and percentage of the sample $(N=200)$

\begin{tabular}{|c|c|c|c|c|c|}
\hline Demographic variables & $\begin{array}{l}\text { Teachers } \\
f(\%)\end{array}$ & $\begin{array}{l}\text { Mothers } \\
f(\%)\end{array}$ & $\begin{array}{l}\text { Fathers } \\
f(\%)\end{array}$ & Demographic variables & $\begin{array}{l}\text { Boys } \\
f(\%)\end{array}$ \\
\hline \multicolumn{6}{|l|}{ Informants ‘Age range } \\
\hline ( in years) & & & & Boys age(years) & \\
\hline $25-35$ & $35(81)$ & $140(70)$ & $120(60)$ & 8- 10 & 30(15) \\
\hline $36-50$ & $8(19)$ & $60(30)$ & $80(40)$ & $11-13$ & $94(47)$ \\
\hline Gender & & & & $14-15$ & $76(38)$ \\
\hline Male & $23(53)$ & & & Class/Grades & \\
\hline Female & $20(47)$ & & & $3-4$ & $27(13.5)$ \\
\hline Academic qualification & & & & $5-6$ & $53(26.5)$ \\
\hline Illiterate & & $12(6)$ & $8(4)$ & $7-8$ & $75(37.5)$ \\
\hline \multirow[t]{2}{*}{ Up to matric } & & $122(61)$ & $110(55)$ & $9-10$ & $45(22.5)$ \\
\hline & & & & Monthly Family & \\
\hline Inter-and Graduates & $26(60)^{a}$ & $56(28)$ & $63(32)$ & income in rupees & \\
\hline \multicolumn{6}{|l|}{ Post-graduation/ } \\
\hline Above and & $17(40)$ & & & & $131(65)$ \\
\hline professional degree & & 10(5) & 19(10) & $5000-25000$ & \\
\hline skilled labour & & & $68(34)$ & $51000-75000$ & $8(4)$ \\
\hline small business & & $20(10)$ & $67(34)$ & $76000-10000$ & $3(2)$ \\
\hline \multicolumn{6}{|l|}{ Low rank private and } \\
\hline govt. job & & & $8(4)$ & $>10000$ & $4(2)$ \\
\hline \multicolumn{6}{|l|}{ High rank private and } \\
\hline govt. job & & & $35(18)$ & & \\
\hline Large scale business & & & $22(11)$ & & \\
\hline House wives & & $169(85)$ & & & \\
\hline School teachers & & $11(6)$ & & & \\
\hline
\end{tabular}




\subsection{Materials:}

Demographic information sheet: It was used to gain basic demographic information about boys from the parents about their child's age, school year, no. of siblings, parents'educational level, occupation and family income level.

Child and Adolescent Disruptive Behavior Inventory: Version 5.0 Burns [26].

This inventory assesses the symptoms of oppositional disorder, attentional skills, activity level and current academic performance and social behavior. It has separate versions Parents as well as teachers. Parents and teacher versions were used separately.Parents rate the occurrence of the ODD-Adults, ODDChildren, ADHD-HI, and ADHD-IN symptoms on an 8-point frequency of occurrence scale for the past month (i.e., $1=$ never in the past month and $8=10$ or more times per day) in the home while the teachers will rate the children on the same sub scales in the school environment. Forthe present study, scale was translated in to Urdu with due permission by the author. The Cronbach's alpha for a total sample of 200 on parent Urdu version for all scales were ranging from .78 - .89. For teacher version it came out to equally good i.e. Cronbach's alpha ranging from $.87-.91$.

Parenting Styles and Dimension Questionnaire (Robinson, Mandelco,Olsen \& Hart, [27].

A 32-item scale designed to assess various parenting styles and practices. The PSDQ is a shortened version of the 62-item Parenting Practices Questionnaire (PPQ). It is based on three typologies: authoritative, authoritarian, and permissive. The authoritative typology is assessed using 15 items that are divided into three subscales: 1) Warmth and Involvement, 2) Reason/Induction, and 3) Democratic Participation. Authoritarian parenting behavior is measured using 12 items divided into three subscales: 1) Verbal Hostility, 2) physical Punishment,) Non reasoning and punitive strategies,). Permissive parenting is assessed with 5 items. The items are rated on five point scale $1=$ Never, $2=$ Once In A while, $3=$ About Half of the Time, $4=$ Very Often and $5=$ always.For the present study, scale was translated in to Urdu with due permission by the author. The Cronbach's alpha for the present study derived on the bases of total sample are $.88, .86$ and .70 authoritative, authoritarian and permissive respectively.

4.3. Procedure: To collect the data from schools permission was seek through the office of Director Public schools Punjab. The list of schools was obtained from the same office. Nine schools were selected randomly. To seek permission for data collection, the school authorities were contacted. Of those, 9 schools, 5 agreed to participate. After getting the permission from the school authority, the class teachers from class three to ten, who had taught children at least for last six months, were invited to participate in the study. These willing teachers were further asked to select boys from their classes for showing any persistent problems of noncompliance, anger and resentment toward others or have difficulty in following the rules.Boys having at least three of these symptoms of oppositional behaviour as reported by class teachers were included. After this, consent forms along with information sheets were sent to teachers and parent both. All contacted teachers except for one agreed to participate. Teachers rated the boysbehavior in school setting while mothers rated their sons'behavior in home setting. Then parents of selected boys were contacted through school. Mothers were required to fill in two questionnaires i.e., one for assessing boys' behavior and the $2^{\text {nd }}$ questionnaire about their parenting discipline. Fathers rated about their own parenting strategies on a separate form.

\section{Results}

The statistical analysis pertaining to the hypotheses of the present study are presented from table 2-8.

Table 2

Correlation among parenting styles and practices of mothers with mother reported oppositional behaviour (home) and teacher reported oppositional behaviour (school) $(N=200)$.

\begin{tabular}{|c|c|c|c|c|}
\hline $\begin{array}{l}\text { Parenting styles } \\
\text { and dimensions }\end{array}$ & $\begin{array}{l}\text { Mother } \\
\text { reported adult } \\
\text { oppositional }\end{array}$ & $\begin{array}{l}\text { Mother } \\
\text { reported peer } \\
\text { oppositional }\end{array}$ & $\begin{array}{l}\text { Teacher } \\
\text { reported adult } \\
\text { oppositional }\end{array}$ & $\begin{array}{l}\text { Teacher reported } \\
\text { peer } \\
\text { oppositional }\end{array}$ \\
\hline $\begin{array}{l}\text { Authoritative } \\
\text { overall }\end{array}$ & -.01 & -.01 & -.09 & -.04 \\
\hline $\begin{array}{l}\text { Warmth } \\
\text { connection }\end{array}$ & -.05 & -.01 & -.09 & -.03 \\
\hline Regulation & .07 & -.01 & -.06 & -.02 \\
\hline
\end{tabular}




\begin{tabular}{lllll}
\hline Autonomy granting & .01 & -.00 & -.07 & -.06 \\
Authoritarian over & $.34 * *$ & $.30^{* *}$ & $.14^{*}$ & .13 \\
all & $.26^{* *}$ & $.25^{* *}$ & .08 & .10 \\
Physical coercion & $.32 * *$ & $.26^{* *}$ & $.18^{*}$ & $.19 * *$ \\
Verbal hostility & $.22^{* *}$ & $.21^{* *}$ & .07 & .00 \\
Non reasoning & $.07 *$ & $.21^{* *}$ \\
\hline Permissive over all & $.34^{* *}$ & $.34^{* *}$ & $.15^{*}$ &
\end{tabular}

Note. ${ }^{*} \mathrm{P}<.05, \quad * * \mathrm{p}<.01$

The results indicated that there was a significant positive relationship among authoritarian overall and permissive over all parenting styles of mothers with boys' oppositional behaviour toward adults and toward siblings in home settings. For teacher's reports, there was significant positive correlation between authoritarian overall, and teacher reported oppositional behaviour toward adult, while permissive overall was significantly related to both targets adults and peers as well. The parenting dimensions of Physical coercion, verbal hostility and non- reasoning were positively correlated with both targets( adults and siblings) in home settings, while in the school setting the dimension of verbal hostility was significantly correlated with oppositional toward adults and toward siblings.

Table 3

Correlation amongparenting styles and practices of fatherswith mother reported oppositional behaviour (home) and teacher reported oppositional behaviour (school) $(N=200)$

\begin{tabular}{|c|c|c|c|c|}
\hline $\begin{array}{ll}\text { Parenting } & \\
\text { styles } & \text { and } \\
\text { practices } & \end{array}$ & $\begin{array}{l}\text { Mother reported } \\
\text { adult } \\
\text { oppositional }\end{array}$ & $\begin{array}{l}\text { Mother reported } \\
\text { sibling } \\
\text { oppositional }\end{array}$ & $\begin{array}{l}\text { Teacher reported } \\
\text { adult } \\
\text { oppositional }\end{array}$ & $\begin{array}{l}\text { Teacher reported } \\
\text { peer oppositional }\end{array}$ \\
\hline $\begin{array}{l}\text { Authoritative } \\
\text { overall }\end{array}$ & $-.17 *$ & $-.21 * *$ & -.01 & .00 \\
\hline $\begin{array}{l}\text { Warmth and } \\
\text { connection }\end{array}$ & -.13 & -.13 & -.03 & -.04 \\
\hline Regulation & -.11 & $-.18 * *$ & .08 & .09 \\
\hline $\begin{array}{l}\text { Autonomy } \\
\text { granting }\end{array}$ & $-.20 * *$ & $-.23 * *$ & -.08 & -.04 \\
\hline $\begin{array}{l}\text { Authoritarian } \\
\text { overall }\end{array}$ & $.42 * *$ & $.35^{* *}$ & $.24 * *$ & $.28 * *$ \\
\hline $\begin{array}{l}\text { Physical } \\
\text { coercion }\end{array}$ & $.39 * *$ & $.33^{* *}$ & $.20 * *$ & $.26^{*}$ \\
\hline $\begin{array}{l}\text { Verbal } \\
\text { hostility }\end{array}$ & $.34 * *$ & $.29 * *$ & $.26^{* *}$ & $.21^{* *}$ \\
\hline Non reasoning & $.30 * *$ & $.23^{* *}$ & .11 & .09 \\
\hline $\begin{array}{l}\text { Permissive } \\
\text { overall }\end{array}$ & $.37 * *$ & $.28 * *$ & .12 & $.17 * *$ \\
\hline
\end{tabular}

The results indicated that there was a significant negative relationship between authoritative overall style of father with oppositional behaviour towards adult and siblings in home setting. The parenting dimensions relating to authoritative style including autonomy granting and regulation were inversely related to oppositional behaviour, however former was related to both targets of oppositional behaviour and later was to oppositional behaviour against siblings only. Whilst there was significant positive relationship among authoritarian overall and permissive overall parenting styles of fathers with boys' oppositional behaviour toward both targets in home setting.'

Whereas in school setting fathers' authoritarian style had significant correlation with oppositional behaviour toward both targets, however permissive overall was significantly correlated with oppositional toward peers only. The practices associated with authoritarian style including (Physical coercion and verbal hostility) were positively correlated with mother as well as teacher reported oppositional behaviour towards both above mentioned targets in both settings. Whereas non-reasoning was significantly correlated with oppositional behaviour toward both targets in home. 
Table 4

Correlation between mother reported oppositional behaviour (home) and teacher reported oppositional behaviour (school) $(N=200)$

\begin{tabular}{|c|c|c|c|}
\hline Variables & $\begin{array}{l}\text { Mother } \\
\text { oppositional } \\
\text { adults }\end{array}$ & $\begin{array}{r}\text { reported } \\
\text { toward }\end{array}$ & $\begin{array}{l}\text { Mother reported oppositional } \\
\text { toward peer }\end{array}$ \\
\hline $\begin{array}{l}\text { Teacher reported } \\
\text { oppositional } \\
\text { toward adults }\end{array}$ & $.28 * *$ & & $.22 * *$ \\
\hline $\begin{array}{l}\text { Teacher reported } \\
\text { oppositional } \\
\text { toward peers }\end{array}$ & $.30 * *$ & & $.26^{* *}$ \\
\hline
\end{tabular}

The results indicated that there was a significant positive correlation between oppositional behavior against two targets in both settings as reported by mother and teacher

\section{Table 5}

Hierarchical Regression Analyses for mother and teacher reported attention deficit, hyper activity and Parenting Styles Predicting mother reported oppositional behaviourtoward adults and siblings in home setting $(N=200)$.

\begin{tabular}{|c|c|c|c|c|}
\hline & \multicolumn{4}{|c|}{ Source for reporting oppositional behaviour } \\
\hline & \multicolumn{4}{|c|}{ Mother } \\
\hline & \multicolumn{2}{|c|}{ Oppositional toward adult } & \multicolumn{2}{|c|}{ Oppositional toward siblings } \\
\hline Predictor & $\Delta \mathrm{R}^{2}$ & $\beta$ & $\Delta \mathrm{R}^{2}$ & $\mathrm{~B}$ \\
\hline Step 1 & $.37 *$ & & $.49 *$ & \\
\hline $\begin{array}{l}\text { Mother- } \\
\text { report hyper } \\
\text { activity }\end{array}$ & & $.31 *$ & & $.45^{*}$ \\
\hline $\begin{array}{l}\text { Mother- } \\
\text { report } \\
\text { attention } \\
\text { deficit }\end{array}$ & & $.31 *$ & & $.32 *$ \\
\hline $\begin{array}{l}\text { Teacher- } \\
\text { report } \\
\text { activity level }\end{array}$ & & .07 & & .02 \\
\hline $\begin{array}{l}\text { Teacher- } \\
\text { report } \\
\text { attention } \\
\text { skills }\end{array}$ & & .02 & & -.01 \\
\hline Step 2 & $.04 *$ & & $.03 *$ & \\
\hline $\begin{array}{l}\text { Mother- } \\
\text { authoritarian }\end{array}$ & & .07 & & .04 \\
\hline $\begin{array}{l}\text { Mother- } \\
\text { permissive }\end{array}$ & & .04 & & $.11^{*}$ \\
\hline $\begin{array}{l}\text { Father- } \\
\text { authoritative }\end{array}$ & & -.09 & & $-.12 *$ \\
\hline $\begin{array}{l}\text { Father- } \\
\text { authoritarian }\end{array}$ & & .05 & & .00 \\
\hline $\begin{array}{l}\text { Father- } \\
\text { permissive }\end{array}$ & & $.14 *$ & & .03 \\
\hline Total $\mathrm{R}^{2}$ & $.48^{*}$ & & $.57 *$ & \\
\hline $\mathrm{N}=$ & 200 & & 200 & \\
\hline
\end{tabular}

Note. ${ }^{*} p<.05$

The results of analysis indicated that over all model predicting mother reported oppositional behaviour toward adult (home setting) by parenting styles and ADHD is significant $(\mathrm{F}=14.92, \mathrm{p}<.05)$, Total $\mathrm{R}^{2}$ suggesting $48 \%$ variance in the outcome due to the predictors. Variables of mother report hyper activity 
\& Mother report attention deficit at $1^{\text {st }}$ step contributing $37 \%$ of the total variation in the model. In step 2 , father permissiveness was the only contributing predictor, $\Delta \mathrm{R}^{2}$ change indicating $4 \%$ of the total variation in the model.

The second regression model predicting mother reported oppositional behaviour toward siblings (home setting) is significant $(\mathrm{F}=23.41, \mathrm{p}<.05)$. On the first step the mother reports on attention skills deficits and hyper activity predicted positively explaining $49 \%$ of variation and on $2^{\text {nd }}$ stepmother's permissiveness positively and fathers' authoritative style negatively predicted oppositional toward siblings, contributing $3 \%$ of total variation.

Table 6

Hierarchical Regression Analyses for both mother \& teacher reported attention deficit \& hyper activity and Parenting Styles Predicting teacher reported oppositional behaviour toward adults and toward peer in school $(N=200)$.

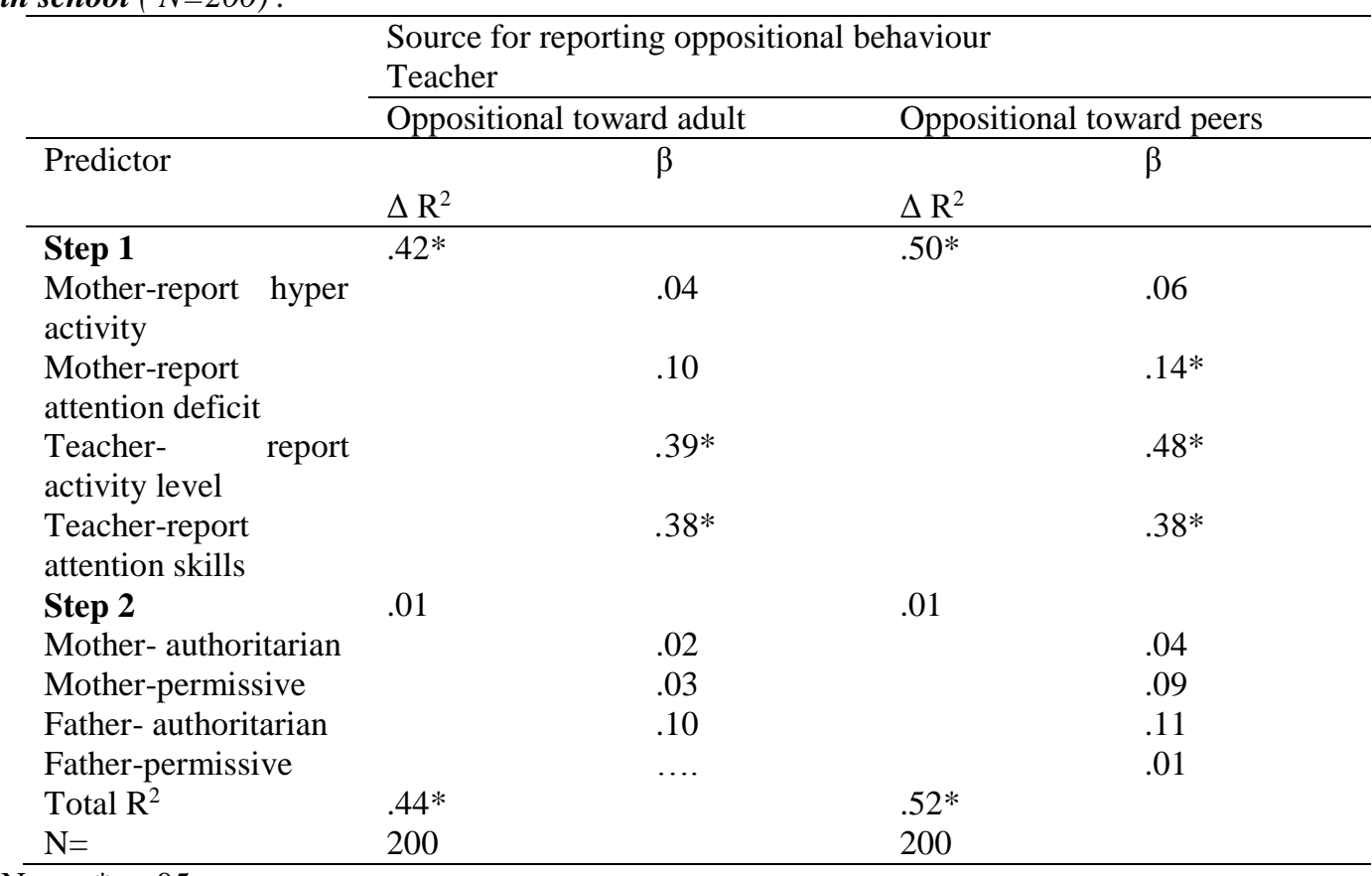

Note. $* \mathrm{p}<.05$,

The results of analysis indicated that Overall model for predicting teacher reported oppositional behavior toward adult (in school) was found to be significant $(F=21.56, \mathrm{p}<.001)$. Total $\mathrm{R}^{2}=.44$. Value for total $R^{2}$ indicates that $44 \%$ variation is accounted by the variables in the model. Two variables i.e., teacher reported hyperactivity and teacher reported attention deficit as indicated by significant $\beta$ predicted oppositional toward adults only at step 1.

The results of the $2^{\text {nd }}$ analysis of the indicated that over all model for predicting teacher reported oppositional behavior toward peers (in school) is significant $(F=29.81, \mathrm{p}<.001)$. Total $R^{2}=.52$ Value for total $R^{2}$ indicates that $52 \%$ variation in outcome variable is due to the variables in the model. However variables including mother-report attention deficit, teacher- report activity level\&teacher-report attention skills were the significant predictors only at step 1 .

Table 7

Hierarchical Regression Analyses for both mother\& teacher reported attention deficit, hyper activity, and ParentingPractices Predicting mother reported oppositional behaviour toward adults and siblings $(N=200)$.

\begin{tabular}{|c|c|c|c|c|c|}
\hline & \multicolumn{4}{|c|}{ Source for reporting the oppositional behaviour } \\
\hline & & \multicolumn{4}{|c|}{ Mother } \\
\hline & & \multicolumn{2}{|c|}{ Oppositional toward adult } & \multicolumn{2}{|c|}{ Oppositional toward siblings } \\
\hline Predictor & & $\Delta \mathrm{R}^{2}$ & $\beta$ & $\Delta \mathrm{R} 2$ & $\mathrm{~B}$ \\
\hline Step 1 & & $.38 *$ & & $.48 *$ & \\
\hline $\begin{array}{l}\text { Mother } \\
\text { activity level }\end{array}$ & report & & $.33 *$ & & $.31 *$ \\
\hline Mother & report & & $.33 *$ & & $.46^{*}$ \\
\hline
\end{tabular}




\begin{tabular}{|c|c|c|c|c|}
\hline attention skills & & & & \\
\hline $\begin{array}{ll}\text { Teacher } & \text { report } \\
\text { activity level } & \end{array}$ & & .00 & & .02 \\
\hline $\begin{array}{l}\text { Teacher report } \\
\text { attention skills }\end{array}$ & & .06 & & .02 \\
\hline Step 2 & $.06^{*}$ & & $.03 *$ & \\
\hline physical & & -.05 & & .00 \\
\hline $\begin{array}{ll}\text { mother } & \text { verbal } \\
\text { hostility } & \end{array}$ & & $.14^{*}$ & & .03 \\
\hline mother permissive & & .06 & & $.12 *$ \\
\hline $\begin{array}{ll}\text { father } & \text { autonomy } \\
\text { granting } & \end{array}$ & & $-.18^{*}$ & & $-.16^{*}$ \\
\hline $\begin{array}{l}\text { father physical } \\
\text { coercion }\end{array}$ & & .02 & & .09 \\
\hline $\begin{array}{l}\text { Father non reasoning } \\
\text { father permissive }\end{array}$ & & $\begin{array}{l}.04 \\
.15^{*}\end{array}$ & & .04 \\
\hline Total $\mathrm{R}^{2}$ & .51 & & .58 & \\
\hline $\mathrm{N}=$ & 200 & & 200 & \\
\hline
\end{tabular}

Note. ${ }^{*} \mathrm{p}<.05$,

The regression analysis was carried out to investigate the contribution of specific practices adopted by parents for predicting mother reported oppositional behaviour toward adult. The results of analysis indicate that over all model is significant $(\mathrm{F}=11.90, \mathrm{p}<.001)$, Total $\mathrm{R}^{2}$ suggesting $51 \%$ variance in the outcome due to the predictors. The steps in table show the sequence for predictors entered into different steps/ blocks.At 1st step (mother report activity level, mother report attention skills) is contributing 38\% of the total variation in the model. In step 2, different parenting practices were entered, mother verbal hostility, father permissiveness indulgence dimension and father autonomy granting were came out to be contributing predictor and $\Delta \mathrm{R}^{2}$ change indicating $6 \%$ of the total variation in the model.

The results of 2 nd analysis predicting mother reported oppositional behaviour toward siblings from parenting practices indicated that over all model is significant $(F=18.82, p<.001)$, Total $R^{2}$ suggesting $58 \%$ variance in the outcome due to the predictors. In the step1 variables mother report activity level and mother report attention skills contributed $48 \%$ of the total variation in the model. In step 2, father autonomy granting negatively and mother permissive indulgence dimension were positively contributing predictor and $\Delta \mathrm{R}^{2}$ change indicating $3 \%$ of the total variation in the model.

Table 8

Hierarchical Regression Analyses for both mother \& teacher reported attention deficit, hyper activity, and ParentingPracticesforpredicting teacher reported oppositional behaviour toward adults and toward peers. $(N=200)$

\begin{tabular}{|c|c|c|c|c|}
\hline \multirow[t]{3}{*}{ Predictor } & \multicolumn{4}{|c|}{ Source for reporting oppositional behaviour } \\
\hline & \multicolumn{4}{|c|}{ Teacher } \\
\hline & \multicolumn{2}{|c|}{ Oppositional toward adult } & \multicolumn{2}{|c|}{ Oppositional toward peers } \\
\hline & $\Delta \mathrm{R}^{2}$ & $\beta$ & $\Delta \mathrm{R}^{2}$ & B \\
\hline Step 1 & & & $.50 * *$ & \\
\hline $\begin{array}{l}\text { Mother-report hyper } \\
\text { activity }\end{array}$ & & .04 & & .06 \\
\hline $\begin{array}{l}\text { Mother-report } \\
\text { attention deficit }\end{array}$ & & .10 & & $.14^{*}$ \\
\hline $\begin{array}{ll}\text { Teacher- } & \text { report } \\
\text { activity level } & \end{array}$ & & $.39 *$ & & $.43^{*}$ \\
\hline $\begin{array}{l}\text { Teacher-report } \\
\text { attention skills }\end{array}$ & & $.38^{*}$ & & $.38^{*}$ \\
\hline Step 2 & .01 & & .02 & \\
\hline Mother-permissive & & .03 & & .09 \\
\hline $\begin{array}{l}\text { Mother-verbal } \\
\text { Hostility }\end{array}$ & & .01 & & .02 \\
\hline $\begin{array}{l}\text { Father-physical } \\
\text { coercion }\end{array}$ & & .02 & & .04 \\
\hline
\end{tabular}




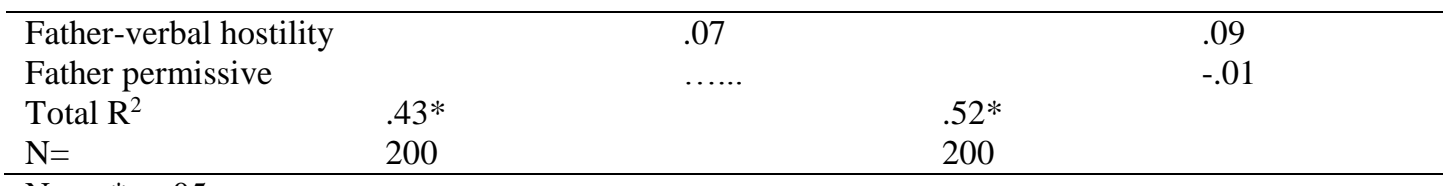

Note. ${ }^{*} \mathrm{p}<.05$

The table displays the findings for two separate hierarchical regression analysis, outcome variables consisted of a) teacher reported oppositional toward adults b) teacher reported oppositional toward peers. To predict oppositional behaviour toward adult in school setting from parenting practices and other variables we found Total $\mathrm{R}^{2}=.43$ which indicates that $43 \%$ variation is accounted for by the proposed model. The overall model for predicting teacher reported oppositional behaviour toward adult was found to be significant $(\mathrm{F}=18.56, \mathrm{p}<.001)$. The first model explains the maximum contribution in the model i.e. $42 \%$ teacher reported attention deficit and teacher reported hyperactivity came out to be as significant predictor, while there was almost only $1 \%$ contribution for the second set of variables including parenting practices.

To predict teacher reported oppositional behaviour toward peer the hierarchical regression analysis was carried out. The overall model for predicting teacher reported oppositional behaviour toward adult was found to be significant $(F=18.56, \mathrm{p}<.001)$. Total $R^{2}=.52$ which indicates that $52 \%$ variation is accounted for by the proposed model. The variables including teacher reported attention deficit and teacher reported hyperactivity and mother reported attention deficit in first step explain the maximum i.e. 50\% contribution in the model.

6. Discussion :The purpose of this study was to examine the relationship among parenting styles, practices and ADHD with oppositional behaviour (OB) toward adult and toward sibling/ peer in home and school setting. Findings of the present research revealed that parenting styles and practices has association with oppositional behaviour toward adults and siblings in both settings. For mothers and fathers both, there was found to be significant relationship among ineffective parenting styles i.e., authoritarian parenting style, three related practices (physical coercion, verbal hostility and nonreasoning) and oppositional behaviour. Corroborating from the previous research that showed a link between punitive and inconsistent parenting practices with the emergence of child antagonism and hostile behaviours [28,29]. Permissive parenting styles of both parents based on indulgence dimension were also found to be significantly associated with OB toward adults, toward siblings and came out to be significant predictor in home settingas well. A study by Gryckowski, Jordan and Mercer [30]gives support to these findings, they reported that mother's loose /indulgent attitude was related to disruptive behaviour of both boys and girls. Whereas another study have found the significant relationship between permissive parenting and disruptive behavior of boys only (e.g., Kim, Park, Cheon, Kim, Cho,\& Hong, [25].

Additionally we also found a significant negative relationship between fathers' authoritative style and oppositional behaviour toward adult and siblings, which came out to be negligible in relation to mothers' authoritative style.The Regression analysis also indicated that fathers' authoritative overall, fathers' autonomy granting practice was negative predictor esp. in home setting. Previous research on children emotional and behaviour problems had suggested that authoritative parenting style in comparison to other styles has positive gains [31]. The findings regarding relationship among ineffective parenting styles and teacher reported oppositional behaviour were according to the assumptions. The fathers' \& mothers' authoritarian stylepractice of verbal hostility by both parents and physical coercion by fathers showed significant relationship with $\mathrm{OB}$; however none of the parenting style of either parent could predict $\mathrm{OB}$ in school setting. For a possible explanation we may consider the findings of another hypothesised relationship between $\mathrm{OB}$ in home and $\mathrm{OB}$ in school, there was a significant moderate relation of OB between two settings. From this, it seems reasonable to assume that OB in two settings might have common and some differential correlates/ predictors. The findings further indicated a significant relationship between ADHD and OB \& regression analysis indicated that hyperactivity and attention deficit predicted strongly OB toward adult \& toward peer. Corroborating from empirical research, there was strong evidence of significant concurrent and sequential comorbidity between ADHD and ODD symptoms in both community and clinical samples of boys and girls between 2 and 17 years of age $[32,33]$.

7. Conclusion. Overall, our findings has shown a significant correlation among parenting styles (authoritarian and permissive) and associated practices of both parents with boys' OB, a significant 
correlation between hyperactivity (HI \&IN type) and OB in home vs. school setting. Among all predictors, attention deficit and hyper activity showed greater contribution in predictingOB toward adults and toward sibling/ peers. On the whole fathers' discipline either positive or negative was found to have more pronounced effect and significantly predicted oppositional toward adults and toward siblings in home as compared to mothers. The Permissive disciplinary strategy appeared to be more salient than authoritarian discipline esp. in home setting. The authoritative father with autonomy granting perspective was additionally found to have protective effect on boys' behavior. The findings draw attention to the fact that oppositional defiant behavior may be situation specific or develop differentially with different targets, have some similar or differential correlates. Therefore a different perspective and treatment approach should be opted, by identifying the specific target or special context.

Limitations. The present study has certain limitations. First the study has small sample, and generally representative of lower middle and middle class family; boys from upper middle class family were not included in the sample, thereby results probably cannot be generalized equally to other groups of children belonging to different family / economic background. Another issue concerns the non-clinical nature of our sample. Majority of the boys scored within the normal range on CADBI-P and CADBI-T. Thus, the present findings provide information about normal population not clinical population. These limitations give direction to future research.

Thirdly boys' view in understanding their own behaviour and their perceptions about parenting was lacking.

Implications. Overall findings provided us useful information about boys 'problem behaviour, obtaining complete information about their disruptive behaviour (ODD+ ADHD) and parenting factors would appropriately inform intervention strategies that may be adapted to fit the needs of each family and the individual child. The identification of the correlates to the oppositional behaviour is beneficial and quite relevant to researchers, practitioners, teachers, school administration and above all to parents to advance their understanding about boys'problem behaviour.

\section{REFERENCES}

[1] Loeber, R., Burke, J.D., Lahey, B.B., Winters, A., \&Zera, M. (2000). Oppositional defiant and conduct disorder: A review of the past 10 years, part I. Journal of the American Academy of Child and Adolescent Psychiatry, 39, 1468-1484.

[2] American Psychiatric Association (2000).Diagnostic and statistical manual of mentaldisorders (4th ed., TR). Washington, DC: Author.

[3] Lahey B.B, Rathouz, P.J., Van Hulle, C., Urbano, R.C., Krueger RF, Appelgate B, Garriock, H.A., Chapman, D.A., \& Waldman, I.D.(2008). Testing structural models of DSM-IV symptoms of common form of child and adolescent psychopathology.Journal of Abnormal Child Psychology. 36:187-206. [PubMed]

[4] Pardini, D., Obradovic, J., \&Loeber, R. (2006). Interpersonal callousness, hyperactivity/impulsivity, inattention, and conduct problems as precursors to delinquency persistence in boys: a comparison of three grade-based cohorts. Journal of Clinical Child and Adolescent Psychology, 35, 46-59.

[5] Darling, N., \& Steinberg, L. (1993). Parenting style as context: An integrative model.Psychological Bulletin, 113, 487-496.

[6] American Psychiatric Association (2013). Diagnostic and statistical manual of mentaldisorders (5th ed.). Washington, DC: Author.

[7] Del Vecchio, T. D., \& O’Leary, S. G. (2006). Antecedents of toddler aggression: Dysfunctional parenting in mother-toddler dyads. Journal of Clinical Child andAdolescent Psychology, 35(2), 194-202.

[8] Snyder, J., Cramer, A., Afrank, J., \& Patterson, G. R. (2005). The contributions of ineffective discipline and parental hostile attributions of child misbehavior to the development of conduct problems at home and school. DevelopmentalPsychology, 41(1), 30-41.

[9] Loeber, R., \&Stouthamer-Loeber, M. (1986). Family factors as correlates and predictors of juvenile conduct problems and delinquency. In M. H. Tonry\&N. Morris (Eds.), Crime and justice.An annual review of research (pp. 29-149, Vol. 7). Chicago: University of Chicago Press. 
[10] Hart, C. H., Newell, L. D., \& Olsen, S. F. (2003). Parenting skills and social-communicative competence in childhood.In J. O. Greene \& B. R. Burleson (Eds.), Handbook of communication and social interaction skills (pp.753 - 797). Mahwah, NJ: Lawrence Erlbaum Associates.

[11] Baumrind, D. (1989). Rearing competent children.In W. Damon (Ed.), Childdevelopment today and tomorrow (pp. 349-378). San Francisco: Jossey-Bass.

[12] Jewell, J. D. \& Stark, K. D. (2003). Comparing the family environments of adolescents with conduct disorder or depression . Journal of Child and FamilyStudies, 12, 77-89.

[13] Wolfradt, U., Hempel, S., \& Miles, J. (2003). Perceived parenting styles, depersonalization, anxiety, and coping behavior in adolescents.Personalityand Individual Differences, 34(3), 521532.

[14] Alvarez, H. K., \&Ollendick, T. H. (2003). Individual and psychosocial risk factors. In C. A. Essau (Ed.), Conduct and oppositional defiant disorders: Epidemiology,risk factors, and treatment (pp. 97-116). Mahwah, NJ: Lawrence ErlbaumAssociates.

[15] Dodge, K. A. (2002). Mediation, moderation, and mechanisms in how parenting affects children's aggressive behavior. In J. G. Borkowski, S. L. Ramey, \& M. Bristol- Power (Eds.), Parenting and the child's world: Influences onacademic, intellectual, and social-emotional development. Monographs inparenting series (pp. 215-229). Mahwah, NJ: Erlbaum.

[16] Eddy, J. M., Leve, L., \& Fagot, B. (2001). Coercive family processes: A replication and extension of Patterson's coercion. model. Aggressive Behavior, 27, 14-25.

[17] Gardner, R. A. (1989). Family evaluation in child custody mediations, arbitration andlitigation.Creskill, NJ: Creative Therapeutics.

[18] Patterson, G. R. (1986). Performance models for antisocial boys. AmericanPsychologist, 41, 432-444.

[19] Barber, B. K. (1996). Parental psychological control: Revisiting a neglected construct. Child Development, 67(6), 3296-3319.

[20] Pettit, G.S., Laird, R.D., Dodge, K.A., Bates, J.E \&Criss, M.M. (2001).Antecedents and behavior-problem outcomes of parental monitoring and psychological control in early adolescence. Child Development, 72, 583-598. [PubMed]

[21] Stice, E., \& Barrera, M. Jr. (1995). A longitudinal examination of the reciprocal relations betweren perceived parenting and adolescents' substance use and externalizing behaviors. Developmental Psychology, 31(2), 322-334.

[22] Lewis, C. C. (1981). The effects of parental firm control: A reinterpretation of findings. Psychological Bulletin, 90, 547-563.

[23] Sheraz,A\&Najam,N. (2012).Parenting Styles and Oppositional Behaviour among School Going Boys.Journal of Behavioural Sciences, Special Issue, ICAPP.

[24] bikoff, H. (1987). An evaluation of cognitive-behavior therapy for hyperactive children.In B.B. Lahey,\& A. E. Kazdin (Eds.), Advances in clinical childpsychology (Vol. 10, pp. 171 216). New York: Plenum Press.

[25] Kim, H., Arnold, D. H., Fisher, P. H., \&Zeljo, A. (2005). Parenting and preschoolers' symptoms as a function of child gender and SES. Child and Family BehaviorTherapy, 27, 23-41. doi:10.1300/J019v27n02_03.

[26] Burns, G. L. (2010). Child and adolescent disruptive behaviour inventory-version-5.0, Pullman, W.A: Author.

[27] Robinson, C. C., Mandelco, B., Olsen, S. F., \& Hart, C. H. (2001). The parenting styles and dimensions questionaire (PSQD). In B. F. Perlmutter,J. Touliatos\& G. W. Holden (Eds.), Handbook of family measurement techniques: Vol. 3.Instruments \& Index (pp.319 321). Thousand Oaks: Sage.

[28] Danforth, J.S., Barkley, R.A., \& Stokes, T.F. (1991).Observations of parent-child interactions with hyperactive children: Research and clinical implications.Clinical Psychology Review, 11, 703-727.

[29] Hart, C.H., Ladd, G.W., \& Burleson, B.R. (1990). Children's expectations of the outcomes of social strategies: Relations with sociometric status and maternal disciplinary styles. Child Development, 61, 127-137. [PubMed].

[30] Gryckowski, M. R., Jordan, S. S., \& Mercer, S. H. (2010). Differential relations between mothers' and fathers' parenting practices and child externalizing behavior. Journal of Child and Family Studies, 19, 539-546. doi:10.1007/s10826-009-9326-2.

[31] Steinberg, L., Lamborn, S., Darling, N., Mounts, N., 8c Dornbusch, S. M. (1994). Over time changes in adjustment and competence among adolescents from authoritative, authoritarian, indulgent, and neglectful families.Child Development, 65, 754-770. 
[32] Angold, A., Costello, E. J., \&Erkanli, A. (1999). Comorbidity.Journal of ChildPsychology and Psychiatry, 40, 57-88.

[33] Biederman J, Newcorn J, Sprich S. (1991). Comorbidity of attention deficit hyperactivity disorder with conduct, depressive, anxiety, and other disorders.American Journal of Psychiatry, 148, 564-577. [PubMed] 